BADAN PENDIDIKAN DAN

PELATIHAN KEUANGAN

KEMENTERIAN KEUANGAN

REPUBLIK INDONESIA

JURNAL BPPK

\title{
ANALISIS PRAKTIK PENGHINDARAN PAJAK DI BIDANG IMPOR PADA KEPAILITAN PERUSAHAAN EKSPOR IMPOR
}

\author{
Himawan Yusufa, Jaka Isgiyartab, \\ a Kanwil Bea dan Cukai Maluku, Indonesia Email: himawan.yusuf@customs.go.id \\ b Universitas Diponegoro, Indonesia Email: jakais@fe.undip.ac.id
}

\section{INFO ARTIKEL}

\section{SEJARAH ARTIKEL}

Diterima Pertama

24 Februari 2019

Dinyatakan Dapat Dimuat 28 Juni 2019

\section{KATA KUNCI:}

Import Tax

Bankruptcy

Tax Avoidance

Customs

\begin{abstract}
ABSTRAK
ANALISIS PRAKTIK PENGHINDARAN PAJAK DI BIDANG IMPOR PADA KEPAILITAN PERUSAHAAN EKSPOR IMPOR. Pajak di bidang impor merupakan beban pajak yang tinggi bagi perusahaan. Hal ini membuat beberapa perusahaan melakukan upaya untuk mengurangi beban pajak di bidang impor, salah satunya dengan memanfaatkan kepailitan perusahaan. Penelitian ini bertujuan untuk menganalisis praktik penghindaran pajak di bidang impor pada kepailitan perusahaan ekspor impor beserta motivasi yang menyertainya, serta menganalisis efektivitas tindakan yang telah dilakukan Bea dan Cukai dalam mencegah praktik penghindaran pajak. Metode kualitatif dengan pendekatan studi kasus digunakan untuk menganalisis praktik penghindaran pajak pada kepailitan tiga perusahaan ekspor impor yang kemudian disebut dengan inisial XYZ. Berdasarkan hasil analisis, diperoleh kesimpulan bahwa telah terjadi praktik penghindaran pajak pada kepailitan perusahaan dengan berbagai motivasinya. Tindakan Bea dan Cukai untuk mencegah praktik penghindaran pajak selama ini belum efektif karena berbagai kendala.
\end{abstract}

ANALYSIS OF IMPORT TAX AVOIDING PRACTICES IN THE BANKRUPTCY OF EXPORTIMPORT COMPANIES. Import tax is a high tax burden for the company. This makes some company try to reduce the import tax burden, one of which is to utilize a bankruptcy. The study aims to analyze the practice of import tax avoidance in the bankruptcy of companies and its accompanying motivation and to analyze about the effectiveness of Customs actions to prevent the practice of tax avoidance. Qualitative methods with a case study approach are used to analyze tax avoidance practices in bankruptcy of three importexport companies which were then called by the initials XYZ. Based on the results of the analysis, it is concluded that there has been a practice of tax avoidance with various motivations. Customs action to prevent the practice of tax avoidance has been less effective due to various constraints.

\section{PENDAHULUAN}

\subsection{Latar Belakang}

Penelitian ini dilakukan untuk menganalisis kepailitan perusahaan ekspor impor, terkait dengan upaya penghindaran pajak di bidang impor. Kepailitan perusahaan baik di Indonesia dan di luar negeri sering menyisakan utang terhadap negara yang tidak terbayar. Penelitian ini disusun dengan menggunakan metode kualitatif untuk lebih mendalami modus penghindaran pajak di bidang impor dengan memanfaatkan kepailitan perusahaan ekspor impor.

Perdagangan internasional mengalami kemajuan yang sangat pesat baik menyangkut kegiatan di bidang impor maupun ekspor. Data Badan Pusat Statistika (2015) menyebutkan bahwa dalam sepuluh tahun terakhir nilai impor di Indonesia meningkat $600 \%$, sedangkan nilai ekspor meningkat sebesar
300\%. Peningkatan importasi yang demikian tinggi apabila tidak diantisipasi dengan kebijakan yang tepat dapat membahayakan perekonomian nasional dan industri dalam negeri. Kebijakan tersebut salah satunya adalah pengenaan pajak di bidang impor berupa Bea Masuk (BM), Pajak Pertambahan Nilai Impor (PPN Impor), Pajak Pertambahan Nilai Barang Mewah Impor (PPN BM Impor), dan Pajak Penghasilan Impor (PPh Impor) yang pemungutannya dilaksanakan oleh Direktorat Jenderal Bea dan Cukai (DJBC).

Pada sisi lain, pajak di bidang impor merupakan salah satu komponen biaya yang dapat mengurangi laba perusahaan, sehingga beban pajak yang tinggi menyebabkan beberapa perusahaan melakukan manajemen pajak untuk mengurangi beban pajak. Praktik penghindaran pajak di bidang impor sebenarnya lebih sulit untuk dilakukan. Pajak di 
bidang impor melekat pada barang bukan pada laba perusahaan, sehingga perhitungan pajak di bidang impor berbeda dengan pajak lainnya. Pajak di bidang impor tidak dapat dikurangi meskipun kondisi perusahaan merugi karena besarnya nilai pajak tidak dihitung berdasarkan harga jual produk atau keuntungan perusahaan, namun dihitung berdasarkan pada besarnya tarif dan nilai barang yang diimpor.

Pada penelitian sebelumnya diungkapkan bahwa praktik tax avoidance pada kegiatan impor pernah dilakukan dengan memanfaatkan fasilitas tax haven (Gravelle 2015, Johanessen 2014, Taylor dan Richardson 2011) dan skema re-import (Liu, 2013). Pada perkembangannya, praktik tax avoidance di bidang impor telah berkembang lebih luas dengan berbagai modus, salah satunya adalah dengan memanfaatkan kepailitan perusahaan. Hal ini pernah diungkapkan oleh Mantan Direktur Jenderal Pajak, Fuad Rachmany (2013, Komunikasi Personal, 23 September) seperti yang dimuat dalam www.okezone.com (23 September 2013) yang menyatakan bahwa: "Lemahnya sistem administrasi ikut menyebabkan tingginya piutang pajak yang tidak tertagih oleh negara. Ada perusahaan yang mempailitkan perusahaannya untuk menghindari utang pajak yang sudah tertumpuk tinggi. Selain perusahaan, Wajib Pajak Orang Pribadi juga, sangat banyak menghindar untuk membayar pajak. Kami kesulitan menjangkau karena alamat KTP Wajib Pajak kadang tidak update dengan keberadaan pemilik KTP”.

Harjono (2009) juga menyatakan bahwa orang dapat mempailitkan perusahaan demi menghindari pajak, karena belum diatur ketentuan mengenai hal itu. Yusril Ihza Mahendra (2012, Komunikasi Personal, 31 Juli) seperti dimuat dalam www.metrobali.com (31 Juli 2015) menyatakan bahwa saat ini UndangUndang Nomor 37 Tahun 2004 tentang Kepailitan dan Penundaan Kewajiban Pembayaran Utang (UUKPKPU) banyak ditafsirkan keliru oleh berbagai kalangan. Menurut Suryana (2013), ketentuan pada UUKPKPU cukup mudah untuk membuat sebuah perusahaan pailit. Pada kasus pajak di bidang impor, pernyataan-pernyataan tersebut didukung oleh data piutang Direktorat Jenderal Bea dan Cukai (DJBC) seperti ditunjukkan dalam Tabel 1.2 berikut:

TABEL 1

\section{STATUS PIUTANG DJBC}

\begin{tabular}{|c|c|c|c|c|c|c|c|}
\hline \multirow{3}{*}{ No } & \multirow{3}{*}{ Status Piutang } & & & & & \multicolumn{2}{|c|}{ (dalam Juta Ripiah) } \\
\hline & & \multicolumn{2}{|c|}{2012} & & 2013 & & 2014 \\
\hline & & Jumlah WP & Nilai & Jumlah WP & Nilai & Jumlah WP & Nilai \\
\hline 1 & DilmpahkanKe KPKNL & & $328,881.63$ & & $216,403.82$ & & $219,119.20$ \\
\hline 2 & WP tidak ditemukan & 11 & $203,734,49$ & 10 & $176,879.47$ & 14 & $58,266.62$ \\
\hline 3 & WP Pailit & 5 & $129,018.83$ & 13 & $149,414.95$ & 22 & $338,089.04$ \\
\hline 4 & Jaminan Tunai & & $31,289.67$ & & $5,316.24$ & & $3,743.98$ \\
\hline 5 & Jaminan Bank & & $1,014,515.41$ & & $2,897,189.98$ & & $1,814,730.33$ \\
\hline 6 & Laimya & & $21,031,548.70$ & & $22,449,905.62$ & & $24,889,003.41$ \\
\hline & TOTAL & & 2,738,98.74 & & 25895,11100 & & $27,32,952.58$ \\
\hline
\end{tabular}

Sumber: LK DJBC, 2012-2014
Pada Tabel 1.1 ditunjukkan bahwa piutang tidak tertagih terhadap Wajib Pajak (WP) pailit jumlahnya semakin meningkat setiap tahun, sehingga diperlukan analisis yang mendalam untuk menilai apakah kepailitan tersebut dimanfaatkan sebagai modus untuk menghindari pajak di bidang impor. Penelitian mengenai perpajakan pada perusahaan pailit telah dilakukan diberbagai Negara.

Beberapa penelitian menunjukkan bahwa perpajakan pada perusahaan pailit banyak yang bermasalah, meskipun tidak terdapat penelitian yang secara jelas menyatakan bahwa kepailitan merupakan salah satu modus tax avoidance. Di Spanyol, meskipun reformasi hukum kepailitan telah dilakukan, namun kepentingan utama dari proses kepailitan adalah untuk para kreditur, bukan untuk kepentingan publik (Medina, 2012). Di Italia, ketentuan mengenai hukum perpajakan dan kebangkrutan masih tumpang tindih sehingga menjadi celah bagi wajib pajak untuk menghindari pembayaran pajak (Tosi, 2005). Permasalahan berbeda ditunjukkan di Amerika Serikat. Menurut Newton (2009), pada perusahaan yang pailit, semua utang pajak dalam periode berjalan dan pajak penjualan aset tetap dibayarkan, namun justru perusahaan yang sering dirugikan karena tidak mendapatkan kompensasi atas kerugian yang dialaminya.

Penelitian ini bertujuan untuk menganalisis praktik penghindaran pajak di bidang impor pada kepailitan perusahaan ekspor impor beserta motivasi yang menyertainya. Penelitian ini dilakukan dengan melakukan studi kasus pada perusahaan pailit yang menyisakan utang pajak, untuk selanjutnya disebut sebagai PT X, PT Y, dan PT Z. Pada penelitian ini dilakukan analisis yang lebih dalam mengenai motivasi perusahaan dan tindakan pemerintah dalam menghadapi hal ini. Penelitian sebelumnya tentang penghindaran pajak pernah dilakukan oleh Dinis, dkk (2015) dengan perbedaan pada fokus penelitian. Penelitian ini hanya pada perusahaan yang diduga pailit karena menghindari utang pajak di bidang impor, sedangkan Dinis, dkk (2015) mengambil sampel seluruh perusahaan yang pailit.

\subsection{Rumusan Masalah}

Pada penelitian ini, dilakukan analisis yang mendalam terhadap praktik penghindaran pajak di bidang impor pada kepailitan perusahaan sampel. Secara lebih rinci, permasalahan dapat dirumuskan sebagai berikut:

1. Bagaimana praktik penghindaran pajak di bidang impor yang dilakukan oleh PT X, PT Y dan PT Z pada kepailitan perusahannya?

2. Bagaimana pejabat DJBC dan pelaku usaha memandang kepailitan PT X, PT Y dan PT Z beserta motivasi yang melatarbelakangi kepailitannya? 
(dalam kaitannya dengan praktik penghindaran pajak di bidang impor)

3. Apa tindakan yang dilakukan DJBC untuk mencegah praktik penghindaran pajak di bidang impor pada kepailitan perusahaan ekspor impor?

4. Bagaimana efektivitas tindakan yang telah dilakukan oleh DJBC dalam menanggulangi praktik tersebut?

\section{KERANGKA TEORITIS DAN PENGEMBANGAN HIPOTESIS.}

Penghindaran pajak yang memanfaatkan kepailitan perusahaan adalah suatu bentuk kecurangan (fraud) terhadap Negara, dan merupakan salah satu bentuk korupsi menurut Undang-Undang No. 31 Tahun 1999 yang telah diubah dengan Undang-Undang No. 20 Tahun 2001 tentang Pemberantasan Tindak Pidana Korupsi yang menyatakan bahwa segala perbuatan yang dapat merugikan keuangan Negara termasuk dalam definisi korupsi. Berdasarkan hal tersebut, penelitian ini didasari oleh teori korupsi.

Pada penelitian ini digunakan Teori Ramirez Torres dan Teori Gone. Teori Ramirez Torres dan Teori Gone adalah teori yang populer untuk menjelaskan kenapa korupsi dapat terjadi serta halhal yang mendorong perbuatan tersebut. Teori Ramirez Torres dan Teori Gone diharapkan dapat memberikan kerangka acuan untuk mengetahui motivasi perusahaan yang melakukan penghindaran pajak dengan memanfaatkan kepailitan perusahaannya serta menjelaskan solusi untuk mencegah praktik tersebut terjadi.

\subsection{Teori Ramirez Torres}

Teori Ramirez Torres dikemukakan oleh seorang akuntan dari Nikaragua bernama Francisco Ramirez Torres pada tahun 1990 dalam bukunya yang berjudul Los delitos económicos en los negocios atau Kejahatan ekonomi dalam bisnis (Tedika, dkk 2013). Francisco Ramirez Torres melakukan penelitian terhadap berbagai penyebab korupsi baik dari pengaruh lingkungan maupun individu. Lingkungan sekolah, keluarga, negara hingga situasi internasional berpengaruh terhadap perilaku korupsi, sedangkan faktor individu yang mempengaruhi korupsi adalah gaya hidup yang buruk, judi, hingga alkohol (Matei, 2013). Teori Ramirez Torres mempunyai rumus yang menjelaskan mengenai penyebab terjadinya korupsi yang dijabarkan dengan persamaan sebagai berikut (Nurina, 2014) :

$$
\begin{aligned}
& \text { Rc }>\text { Pty } x \text { Prob } \\
& \text { Rc } \quad=\text { Reward (Result) of Corruption } \\
& \text { Pty } \quad=\text { Penalty } \\
& \text { Prob } \quad=\text { Probability of being detected/caught }
\end{aligned}
$$

\subsection{Teori Gone}

Jack Bologna adalah seorang akademisi dari Amerika Serikat yang melakukan penelitian mengenai korupsi dan akuntansi forensik. Teks Teori GONE dikemukakan oleh Jack Bologne pada tahun 1993 dalam bukunya yang berudul Handbook of Corporate Fraud. Menurut Sihombing (2014), Teori GONE merupakan penyempurnaan dari teori Triangle Fraud, yang sebelumnya menyebutkan bahwa Pressure (Tekanan), Opportunity (Peluang), Rationalization (Rasionalisasi) adalah alasan mengapa seorang koruptor melakukan tindak fraud. Empat faktor dalam Teori GONE dapat menjelaskan penyebab fraud. Keempat faktor tersebut adalah :

1) Greedy, terkait keserakahan dan kerakusan para pelaku korupsi.

2) Opportunity, sistem yang memberi peluang untuk melakukan korupsi.

3) Needs, sikap mental yang tidak pernah merasa cukup, selalu sarat dengan kebutuhan yang tidak pernah usai.

4) Exposes, hukuman yang dijatuhkan kepada para pelaku korupsi yang tidak memberi efek jera pelaku maupun orang lain.

\subsection{Kepailitan}

Kepailitan berasal dari kata 'pailit' yang berasal dari kata Belanda Failliet. Kata Failliet itu sendiri berasal dari kata bahasa Perancis 'Faillite', yang berarti pemogokan atau kemacetan pembayaran. Jadi, kata 'Pailit' dalam bahasa Indonesia itu dapat diartikan yaitu adanya suatu keadaan berhenti membayar (Ramadhani,2009). Menurut Suwitno (2013), kepailitan adalah kesulitan keuangan yang sangat parah sehingga perusahaan tidak mampu lagi menjalankan operasinya dengan baik, sedangkan dalam Kamus Besar Bahasa Indonesia pailit atau bangkrut mengandung arti menderita kerugian besar hingga jatuh. Kepailitan yang terjadi dalam perusahaan biasanya diawali dengan kesulitan keuangan atau financial distress (Suwitno, 2013). Kepailitan juga sering disebut likuidasi perusahaan atau penutupan perusahaan atau insolvabilitas. Secara umum, definisi kepailitan dapat dilihat dari dua sudut pandang, yaitu kepailitan secara hukum dan kepailitan secara teknis. Menurut Ramadhani (2009), syarat untuk dapat dinyatakan pailit melalui putusan pengadilan adalah:

1) Terdapat minimal 2 orang kreditor;

2) Debitor tidak membayar lunas sedikitnya satu utang; dan

3) Utang tersebut telah jatuh waktu dan dapat ditagih. 
Menurut Harjanti (2015), Pasal 21 ayat (1) dan ayat (3) UU Nomor 16 tahun 2000 tentang Ketentuan Umum dan Tata Cara Perpajakan (UUKUP) mengatur mengenai hak mendahulu sebagai berikut:

1) Negara mempunyai hak mendahulu untuk utang pajak atas barang-barang milik Penanggung Pajak.

2) Hak mendahulu untuk utang pajak melebihi segala hak mendahulu lainnya, kecuali terhadap:

(a) Biaya perkara yang hanya disebabkan oleh suatu penghukuman untuk melelang suatu barang bergerak dan/atau barang tidak bergerak.

(b) Biaya yang telah dikeluarkan untuk menyelamatkan barang dimaksud; dan/atau

(c) Biaya perkara, yang hanya disebabkan oleh pelelangan dan penyelesaian suatu warisan.

\subsection{Tax Avoidance}

Penghindaran pajak (tax avoidance) adalah usaha untuk mengurangi beban pajak yang bersifat legal, sedangkan penggelapan pajak (tax evasion) adalah usaha untuk mengurangi pajak yang bersifat tidak legal (Xynas, 2011). Menurut Hutagaol (2007), tax avoidance adalah cara untuk menghindari pembayaran pajak secara legal yang dilakukan oleh Wajib Pajak dengan cara mengurangi jumlah pajak terutangnya tanpa melanggar peraturan perpajakan atau dengan istilah lainnya mencari kelemahan peraturan. Tax avoidance merupakan tindakan yang tidak melanggar hukum, namun pada dasarnya, praktik tax avoidance dan tax evasion adalah tindakan yang merugikan keuangan Negara.

\subsection{Telaah Penelitian Sebelumnya}

Penelitian mengenai tax avoidance dan tax evasion telah banyak dilakukan. Penelitian terdahulu telah mengungkapkan berbagai modus dan kelemahan sistem perpajakan yang menyebabkan praktik tax avoidance dan tax evasion terjadi. Penelitian tersebut antara lain: Xynas (2011) melakukan penelitian tentang strategi tax avoidance yang digunakan pembayar pajak di Australia pada Tahun 1970-2010 dan respon pemerintah. Hasil penelitian menunjukkan bahwa regulasi yang dikeluarkan oleh Pemerintah belum mampu menunjukkan keadilan dan kurang mendapatkan kepercayaan publik. Liu (2011) melakukan penelitian mengenai aksi tax avoidance menggunakan skema reimport. Hasil penelitian menunjukkan banyak perusahaan di China melakukan ekspor untuk diimpor kembali untuk menghindari pajak pertambahan nilai.

Penelitian ini merupakan pengembangan penelitian sebelumnya yang dilakukan oleh Dinis dan kawan-kawan. Penelitian Dinis, dkk (2015) telah berhasil menunjukkan bahwa telah terjadi tax evasion pada perpajakan perusahaan pailit di Portugis, sedangkan pada penelitian ini tidak hanya menunjukkan penghindaran pajak pada perusahaan yang pailit namun juga dianalisis apakah kepailitan tersebut digunakan sebagai modus penghindaran pajak. Pada penelitian ini dilakukan analisis yang lebih dalam mengenai praktik penghindaran pajak di bidang impor dan motivasi yang melatarbelakangi kepailitannya serta tindakan pemerintah dalam menghadapi hal ini. Perbedaan lain, fokus penelitian ini hanya pada perusahaan yang diduga pailit karena menghindari utang pajak di bidang impor, sedangkan Dinis, dkk (2015) mengambil sampel seluruh perusahaan yang pailit.

\subsection{Kerangka Pemikiran}

Penelitian ini berawal dari dugaan terhadap adanya praktik penghindaran pajak di bidang impor pada kepailitan perusahaan ekspor impor. Hal ini didukung oleh data piutang DJBC terhadap perusahaan pailit telah mencapai 338 Milyar Rupiah pada Tahun 2014, atau cenderung naik setiap tahun. Hal ini harus menjadi perhatian Pemerintah karena perusahaan yang pailit rata-rata tidak mempunyai aset yang cukup untuk membayar kewajibankewajibannya (Harjono, 2009).

Hak Negara adalah prioritas yang harus diselamatkan, oleh karena itu, untuk mencegah praktik ini berkembang lebih luas diperlukan analisis terhadap motivasi perusahaan memilih pailit serta bagaimana praktik penghindaran pajak di bidang impor pada kepailitan perusahaan tersebut dengan menggunakan Teori GONE dan Teori Ramirez Torres sebagai lens of understanding. Tindakan pemerintah juga dianalisis untuk menguji seberapa efektif tindakan tersebut dalam mencegah praktik penghindaran pajak dengan modus tersebut.

Berdasarkan telaah literatur dan penelitian sebelumnya, maka dikembangkan kerangka pemikiran seperti pada Gambar 2.1. Pada kerangka pemikiran tersebut, perusahaan yang mempunyai tagihan pajak dan pailit dianalisis apakah terdapat praktik penghindaran pajak yang merugikan keuangan negara, kemudian berdasarkan Teori Gone dan Teori Ramirez Torres, motivasi kepailitan perusahaan kepailitan tersebut dianalisis. Hasil analisis tersebut dapat menunjukkan apakah kepailitan tersebut digunakan sebagai modus penghindaran pajak di bidang impor. Terakhir, tindakan yang diambil oleh DJBC untuk mencegah praktik penghindaran pajak dan penyelamatan hak Negara dianalisis efektivitasnya. Kerangka pemikiran dapat ditunjukkan sebagaimana gambar berikut.

\section{GAMBAR 2}




\section{KERANGKA PEMIKIRAN}

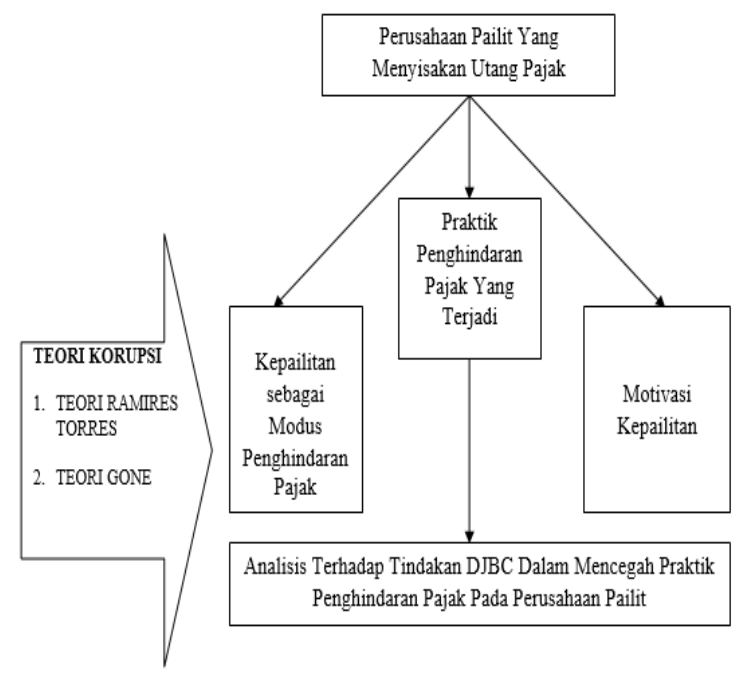

\section{METODOLOGI PENELITIAN}

Sesuai dengan tujuan penelitian, maka metode yang digunakan adalah metode kualitatif. Metode kualitatif dipilih karena data yang bersifat perasaan, norma, keyakinan, kebiasaan, sikap mental dan budaya yang dianut seseorang maupun sekelompok orang dapat ditemukan (Moleong, 2005). Pendekatan yang digunakan dalam penelitian ini adalah studi kasus. Alasan penggunaan pendekatan studi kasus adalah agar dapat memperoleh pemahaman yang tajam terhadap suatu masalah karena dilakukan penelitian yang detail dan mendalam terhadap subyek yang memahami kasus yang terjadi (Key, 1997). Penelitian mengenai tax evasion dan tax avoidance di bidang kepabeanan sampai dengan saat ini belum banyak diteliti di Indonesia.

Penelitian dilakukan di DJBC dan diluar DJBC. Lokasi penelitian di DJBC adalah di Kantor Pusat DJBC yang meliputi Direktorat Penerimaan dan Peraturan Kepabenan dan Cukai (PPKC), Direktorat Informasi Kepabeanan dan Cukai (IKC) dan Kantor Pelayanan, dalam hal ini informasi diperoleh dari Kantor Pelayanan Utama Bea dan Cukai Tanjung Priok. Lokasi diluar DJBC adalah ditempat pelaku usaha, yang akan diwakili oleh Perusahanan Pengurusan jasa Kepabeanan (PPJK) yang mengenal PT X,Y, dan Z. Waktu penelitian dilakukan selama dua bulan, antara bulan September 2015-Oktober 2015. Pada penelitian ini, pengumpulan data dilakukan pada natural setting (kondisi yang alamiah). Sumber data primer dan teknik pengumpulan data lebih banyak pada observasi, wawancara, dan dokumentasi. Informan yang akan menjadi narasumber adalah:

1) Budi Suharto, seorang pejabat DJBC pada seksi penagihan dan pengembalian di Kantor Pusat DJBC;
2) Purnomo, seorang pejabat DJBC yang sebelumnya bekerja pada seksi penagihan Kantor Pelayanan Utama Tanjung Priok selaku pelaksana dilapangan yang berurusan langsung dengan PT X, Y, dan Z;

3) Hari Setyo Nugroho, seorang staf DJBC pada Direktorat Informasi Kepabeanan dan Cukai;

4) Informan1 dan Informan2, adalah pegawai PPJK selaku pihak diluar DJBC yang memahami seluk beluk perusahaan karena mengenal perusahaan yang bersangkutan.

Pada penentuan perusahaan yang akan dijadikan sampel, terlebih dahulu dibuat kriteria atau parameter sehingga perusahaan tersebut layak untuk diambil sebagai sampel. Kriteria perusahaan tersebut adalah sebagai berikut:

1) Perusahaan yang pailit tersebut tercatat dalam outstanding piutang pada Laporan Keuangan DJBC tahun 2014. Hal ini dimaksudkan agar data pada kasus yang terjadi tersedia, dan informasi dapat digali secara maksimal dari para informan mengingat pailitnya perusahaan belum terlalu lama.

2) Jumlah bagian yang diperoleh DJBC tidak lebih dari $50 \%$ dari utang pajaknya. Hal ini sesuai dengan Teori Ramirez Torres yang menyatakan bahwa pelaku korupsi akan mendapatkan keuntungan yang lebih besar daripada resiko yang diterima.

3) Dilayani di Kantor Pelayanan yang terletak di Jakarta dan sekitarnya. Pemilihan domisili perusahaan di Jakarta dan sekitarnya adalah untuk efektivitas waktu dan memudahkan penelitian, mengingat banyak informasi yang berasal kantor pusat DJBC, sehingga tidak perlu ke luar kota untuk menggali informasi berikutnya.

Validitas dan reliabilitas temuan atau data digunakan tiga prosedur, yaitu Triangulasi, menggunakan bahan referensi, dan check member, sedangkan untuk Teknik Analisis digunakan metode yang dikembangkan oleh Miles dan Hubberman. Tiga metode dalam analisis data kualitatif Miles dan Hubberman yaitu reduksi data, penyajian data, penarikan kesimpulan (Zarkasi 2012). Alasan penggunaan teknik analisis ini adalah pada penelitian kualitatif terdapat banyak informasi yang masuk dan informasi tersebut tidak semuanya sesuai dengan tujuan penelitian, sehingga perlu dilakukan reduksi data. Hasil reduksi data, yaitu data tertentu yang dianggap penting akan disajikan, dan kemudian ditarik kesimpulan penelitian.

\section{HASIL DAN PEMBAHASAN}

\subsection{Profil Perusahaan Sampel}


Pada laporan keuangan DJBC tahun 2014, terdapat 179 (seratus tujuh puluh sembilan) tagihan pada perusahaan pailit dengan utang pajak di bidang impor sebesar 336,1 miliar rupiah, serta 7 (tujuh) tagihan cukai sebesar 1,9 miliar rupiah (DJBC, 2015). Utang tersebut merupakan utang tidak tertagih dari 22 (dua puluh dua) perusahaan yang dinyatakan pailit. Perusahaan yang diambil sebagai sampel adalah perusahaan yang memiliki utang pajak di bidang impor dimana bagian yang diperoleh DJBC tidak lebih dari 50\% dari utang pajaknya, beroperasi di Jakarta dan sekitarnya, dan tercatat pada laporan keuangan DJBC tahun 2014 sebagai outstanding piutang. Perusahaan diseleksi dengan cermat agar perusahaan yang terpilih layak diambil sebagai sampel. Berdasarkan seleksi tersebut, diambil tiga buah perusahaan dengan status jalur hijau dan merah untuk mewakili seluruh entitas.

\section{GAMBAR 4.1}

\section{PROFIL PERUSAHAAN SAMPEL}

\section{PROFIL PT X}

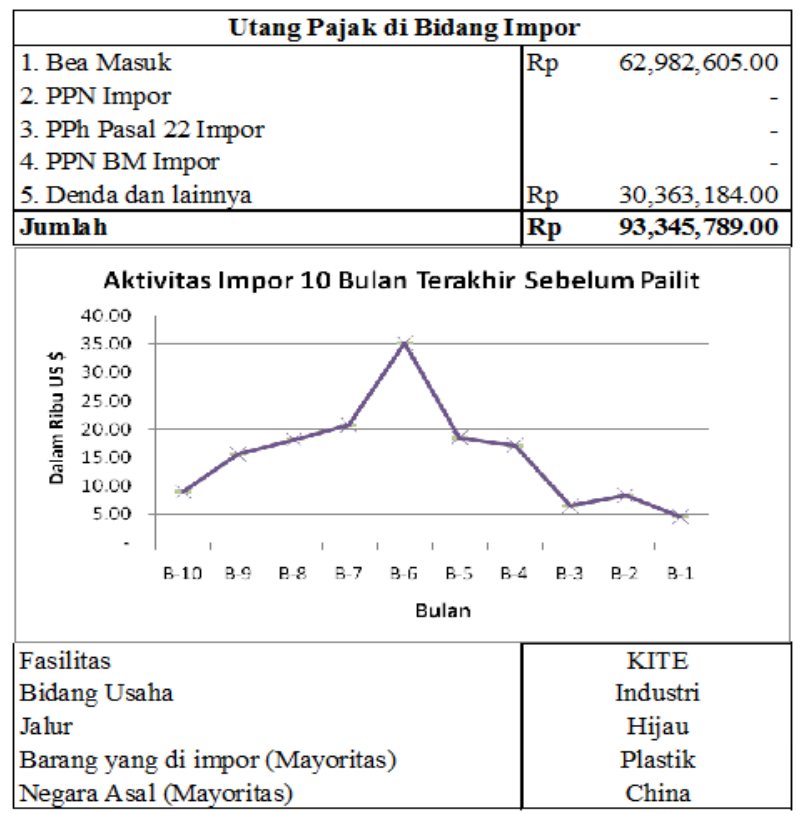

Sumber : SAPP DJBC (2015)

PROFIL PT Y

\begin{tabular}{|l|lr|}
\hline \multicolumn{2}{|c|}{ Utang Pajak di Bidang Impor } \\
\hline 1. Bea Masuk & $\mathrm{Rp}$ & $626,799,500.00$ \\
2. PPN Impor & & - \\
3. PPh Pasal 22 Impor & & - \\
4. PPN BM Impor & & - \\
5. Denda dan lainnya & Rp & $\mathbf{6 2 6 , 7 9 9 , 5 0 0 . 0 0}$ \\
\hline Jumlah
\end{tabular}

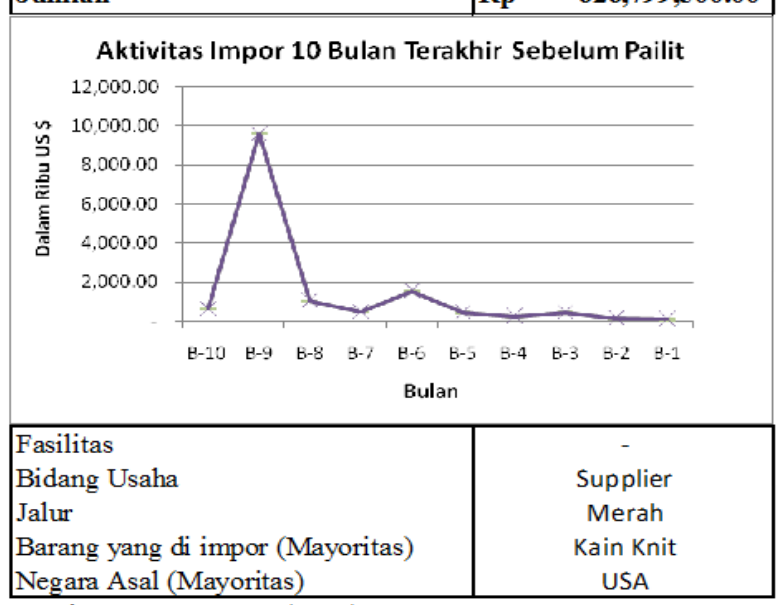

Sumber: SAPP DJBC (2015)

PROFIL PT Z

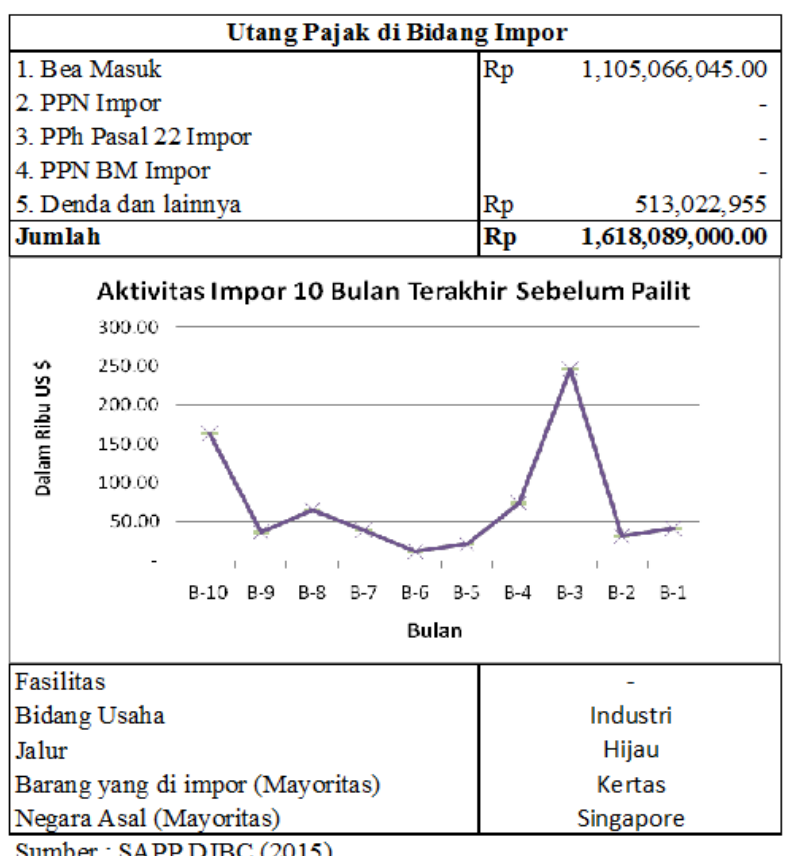

\subsection{Analisis Praktik Penghindaran Pajak Di Bidang Impor Pada Kepailitan PT X, Y, dan Z}

Piutang pajak di bidang impor muncul dari diterbitkannya tagihan. Tagihan tersebut merupakan penetapan tambah bayar atau lebih bayar beserta denda dan/bunga yang diterbitkan oleh pejabat DJBC berdasarkan pemeriksaan atas kesesuaian pemberitahuan pabean dengan kondisi barang sebenarnya, yang meliputi spesifikasi barang, jumlah, kode HS (Harmonized System), nilai pabean, dan tarif. Mengenai kronologis waktu antara terbitnya tagihan dan kepailitan PT X ini, dijelaskan oleh Bapak 
Purnomo, mantan Kepala Seksi Penagihan KPUBC Tanjung Priok:

"Pada kasus PT X ini DJBC terlambat dalam memberikan tagihan, tagihan diterbitkan ketika perusahaan sudah pailit, perusahaan sudah tidak punya kewajiban membayar dan DJBC juga tidak dapat menagih".

Mengenai kronologis waktu antara terbitnya tagihan dan kepailitan PT Y, dijelaskan oleh Bapak Hari Setyo:

"PT Y pailit setelah diaudit, tagihan sudah terbit. Setelah tagihan terbit itu ada waktu untuk membayar kekurangan tagihan, tapi berdasarkan data di SAPP, PT Y ini akan naik banding, karena sebelumnya menyampaikan keberatan, dan keberatan ditolak. Pada saat proses banding ini perusahaan pailit".

SAPP adalah sistem aplikasi yang memonitor status piutang. Dugaan yang muncul adalah dalam perjalanan menuju kepailitannya, PT Y telah melakukan penyamaran atau pemindahan terhadap aset-asetnya, sebagaimana dinyatakan oleh Bapak Purnomo:

“......ini sebelum perusahaan tersebut digugat (dituntut untuk pailit-red), dia menyamarkan asetnya. Aset perusahaan itu dialihkan ke perusahaan afiliasinya atau saudaranya lah, jadi kurator tidak bisa ngambil aset, kenapa kurator tidak bisa ngambil? karena pengalihan asetnya terjadi sebelum pailit. Penyamaran aset ini kan sulit membuktikannya".

Mengenai kronologis waktu antara terbitnya tagihan dan kepailitan PT Z, dijelaskan oleh Bapak Hari Setyo:

"PT Z pailit setelah diaudit dan tagihan sudah terbit, namun PT $\mathrm{Z}$ ini tidak melakukan pembayaran. Berdasarkan data outstanding di SAPP, PT Z ini sudah dapat surat teguran, kemudian surat paksa, sampai akhirnya penyitaan, setelah itu perusahaan pailit"

Penyitaan yang dilakukan DJBC seharusnya dapat menutup sebagian atau seluruh tagihan Negara yang ditanggung PT Z, namun ternyata aset PT Z sudah dialihkan atau bukan atas nama PT Z. Hal ini sebagaimana dinyatakan oleh Bapak Purnomo:

"ini begitu dia tahu akan ditagih, dia menyamarkan kepemilikan asetnya, Penagihan kan yang dikejar asetnya, begitu asetnya sudah bukan nama si pengutang jadi sulit.....".

Pada kepailitan perusahaan ekspor impor tersebut memiliki beberapa persamaan dan perbedaan (variasi). Persamaan tersebut antara lain :
1) PT X, PT Y, dan PT Z pailit setelah diaudit dengan meninggalkan utang terhadap negara.

2) DJBC tidak mendapat bagian sama sekali akibat kepailitan PT X dan PT Z.

3) PT Y dan PT Z diduga telah melakukan penyamaran atau pengalihan aset sehingga DJBC tidak mendapatkan bagian dari kepailitannya.

Perbedaannya antara lain:

1) PT X pailit sebelum penerbitan tagihan, berbeda dengan PT Y dan PT Z.

2) DJBC mendapatkan pembayaran meskipun hanya 50\%, berbeda dengan PT X dan PT Z dimana DJBC tidak mendapatkan bagian sama sekali.

3) PT Y memanfaatkan lamanya waktu pada proses keberatan dan banding untuk melakukan penyamaran atau pengalihan aset-asetnya.

4) PT Z memanfaatkan lamanya waktu pada prosedur penagihan untuk melakukan penyamaran atau pengalihan aset-asetnya.

Berdasarkan pada studi kasus yang dilakukan pada PT X, PT Y, dan PT Z, kepailitan perusahaan tersebut mengakibatkan piutang Negara tidak dapat ditagih. Hal ini membuktikan bahwa praktik penghindaran pajak telah terjadi pada kepailitan perusahaan ekspor impor tersebut. Karakteristik praktik penghindaran pajak adalah negara dirugikan atas hilangnya potensi penerimaan negara dan usaha tersebut dilakukan tanpa melangar peraturan atau dengan kata lain mencari celah dari peraturan yang ada (Hutagaol, 2007). Kerugian Negara timbul akibat tindakan PT X yang memanfaatkan status perusahaan KITE untuk tidak membayar pajak di bidang impor, kemudian tindakan PT Y dan PT Z yang telah melakukan pengalihan aset sebelum putusan pailit. Praktik penghindaran pajak tersebut tidak melanggar ketentuan karena memanfaatkan celah pada ketentuan-ketentuan seperti UU Kepailitan, UU Kepabeanan, UU Penagihan Pajak, dan UU Pengadilan Pajak.

Praktik penghindaran pajak yang terjadi pada kepailitan PT X, PT Y dan PT Z menimbulkan pertanyaan terkait dengan motivasi kepailitan perusahaan tersebut. Pertama, apakah kepailitan digunakan sebagai modus untuk menghindari pajak di bidang impor, kemudian yang kedua, apa yang menjadi pertimbangan perusahaan tersebut pailit. Informan1 sebagai pihak yang mengenal PT X dan PT Y menyampaikan pendapatnya sebagai berikut:

"PT X memang pailit, itu kan pabrik ya, asetnya pasti tidak kecil, kalau soal hubungannya dengan dia tidak membayar kewajiban pajaknya, ya karena dia tahu akan pailit, jadi ya sekalian aja. Mungkin tidak hanya DJBC saja yang punya tagihan ke dia". 
Berbeda dengan PT X, pada kepailitan PT Y, Informan1 menyampaikan pendapatnya sebagai berikut:

"Kejadian seperti PT Y itu, jadi begitu dia kena notul, tidak mau bayar, terus pailit. Jadi memang pailitnya dia itu gara-gara notul, yang seperti ini banyak.......".

Notul atau nota pembetulan merupakan bahasa yang sering digunakan dalam menyebutkan tagihan untuk melakukan koreksi pembayaran.

Pada kepailitan PT Z, Informan2 sebagai pihak yang mengenal PT Z menyampaikan pendapatnya sebagai berikut:

"..... PT Z sempat ditindak oleh DJBC, tapi penyebab utama dia pailit untuk pastinya kurang tahu, karena namanya perusahaan ya, omset naik turun, mungkin karena omset lagi turun, dia rugi, dan utangnya juga banyak ......".

\section{Gambar 4.2}

\section{BAGAN PRAKTIK PENGHINDARAN PAJAK DI BIDANG IMPOR PADA KEPAILITAN PT X, PT Y, DAN PT Z}

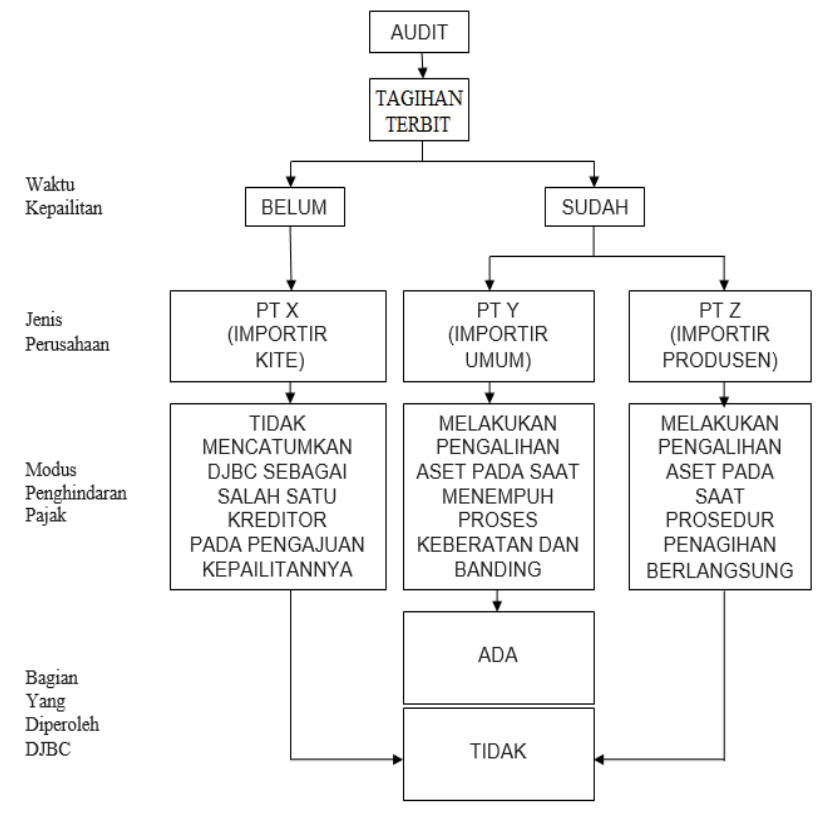

Sumber : Data Primer Diolah (2015)

Berdasarkan hasil wawancara dan pengamatan, diketahui bahwa kepailitan PT X, PT Y, dan PT Z telah mengakibatkan kerugian Negara karena menyebabkan tidak tertagihnya piutang Negara pada ketiga perusahaan tersebut. Praktik penghindaran pajak telah dilakukan oleh ketiganya namun hanya PT Y (importir umum) yang telah menjadikan kepailitan sebagai modus penghindaran pajak di bidang impor, sedangkan pada PT X dan PT Z diduga hanya mengambil manfaat dari pailitnya perusahaan tersebut untuk menghindari pajak di bidang impor.

Pada Teori GONE, rasa tidak pernah cukup (Needs) dan keserakahan untuk mendapatkan hasil yang sebesar-besarnya (Greedy) merupakan sikap mental pada individu yang menyebabkan seseorang melakukan penghindaran pajak. Sikap mental yang rakus dan tidak pernah cukup, akan selalu berusaha mencari peluang untuk keuntungan pribadinya. Hal ini disampaikan oleh Informan1 yang menyatakan:

"..... jadi begitu dia kena notul, tidak mau bayar, terus pailit. Jadi memang pailitnya dia itu gara-gara notul, yang seperti ini banyak......".

Sesuai dengan Teori GONE, perilaku kecurangan tidak akan dilakukan apabila tidak ada kesempatan (opportunity) untuk melakukannya. Kesempatan untuk melakukan kecurangan muncul akibat lemahnya pengawasan atau peraturan. Lemahnya pengawasan DJBC terlihat ketika pengawasan terhadap PT Y tidak ditingkatkan setelah terbitnya tagihan, sehingga lamanya waktu jatuh tempo menjadi kesempatan bagi PT Y untuk mengalihkan aset perusahaannya.

Hukuman yang yang tidak memberi efek jera (exposes) menyebabkan orang berani melakukan kecurangan. Hukuman atau penalty yang pantas harus diberlakukan agar seseorang mengurungkan niatnya untuk berbuat curang. Menyelesaikan utang melalui kepailitan adalah sesuatu yang legal, sehingga DJBC perlu mengantisipasi dengan memberikan hukuman yang tegas dan memberi efek jera bagi setiap orang yang memanfaatkan kepailitan untuk menghindari pajak di bidang impor. Pada kasus penghindaran pajak di bidang impor (yang dilakukan dengan memanfaatkan kepailitan perusahaan), hukuman tidak harus berbentuk pidana, namun dapat juga berupa administratif berupa pemblokiran atau blacklist kepada pengurus perusahaan ketika akan beraktivitas di bidang ekspor impor lagi. Terkait dengan hal tersebut, berikut penuturan Hari Setyo:
"Sistem kita hanya mengunci NPWP perusahaannya, belum sampai NPWP pengurus, sehingga seseorang kalau bikin perusahaan baru lagi ya sudah tidak terlacak utang-utang diperusahaan lama, karena kuncinya di NPWP".

Hal tersebut dipertegas oleh Informan1:
"Ya kalau yang satu ditutup, tinggal bikin baru. Satu orang itu bisa punya puluhan perusahaan, kalau yang satu ke blokir bisa pakai perusahaan yang lain. Lagian DJBC nggak mungkinlah ngecek gitu, ada berapa banyak perusahaan yang mau dicek, sulit itu .....".

Berdasarkan Teori GONE, exposes atau hukuman yang tidak memberi efek jera menyebabkan seseorang berani untuk melakukan praktik penghindaran pajak, sedangkan menurut Teori Ramirez Torres hukuman atau penalty yang diterima bagi pelaku akan dikalkulasi dengan keuntungan yang diperoleh. Pada kasus ini, hukuman yang 
diberikan hanya sebatas pemblokiran, sehingga pengurus PT Y merasa aman dalam melakukan tindakannya tersebut.

Menurut Teori Ramirez Torres, perilaku kecurangan akan memperhatikan besarnya kemungkinan untuk ditangkap (Probability of being detected/caught) dan hasil yang diperoleh. Pada kasus PT Y, hasil yang diterima jelas lebih besar dari hukuman dan kemungkinan untuk ditangkap. Kepailitan justru memperkecil kemungkinan PT Y untuk diproses lebih lanjut, sebagaimana disampaikan oleh Informan2 yang menyatakan bahwa kepailitan justru memberi rasa aman dari tagihan utang karena merasa utangnya telah lunas. Menurut Teori Ramirez Torres Probability of being detected/caught yang diterima bagi pelaku akan dikalkulasi dengan keuntungan yang diperoleh.

\subsection{Tindakan DJBC Dalam Mencegah Praktik Penghindaran Pajak Di Bidang Impor Pada Kepailitan Perusahaan Ekspor Impor}

Praktik penghindaran pajak di bidang impor dengan memanfaatkan kepailitan perusahaan harus diperhatikan secara serius oleh Pemerintah. Hal ini terlihat dari piutang negara yang tidak tertagih (dari tahun 2012 sampai dengan 2014) pada perusahaan pailit terus mengalami peningkatan (Tabel 1). Praktik penghindaran pajak di bidang impor pada kepailitan perusahaan ekspor impor terjadi karena sebelumnya kasus seperti ini kurang mendapatkan perhatian dari DJBC, sebagaimana dinyatakan oleh Bapak Budi Suharto berikut ini:

\begin{abstract}
“...dulu kita memang sempat kecolongan, mungkin karena fokus perhatiannya bukan pada perusahaan yang pailit ini, namun sekarang kita menaruh perhatian yang tinggi terhadap perusahaan-perusahaan pailit ini, kemain juga ada kejadian di Medan yang kita kerjakan......".
\end{abstract}

Tindakan DJBC sebelumnya dilakukan dengan cara konvensional sesuai dengan prosedur penagihan pada UU Penagihan Pajak, yaitu menunggu waktu jatuh tempo, memberikan surat teguran, menerbitkan surat paksa, kemudian melakukan penyitaan. Berdasarkan studi kasus pada PT X, PT Y dan PT Z, DJBC hanya melakukan penagihan aktif, sedangkan upaya preventif terhadap perusahaan yang mempunyai utang pajak belum dilakukan, hal ini dibuktikan dengan fakta-fakta berikut ini:

1) Kepailitan PT $X$ tidak diketahui oleh DJBC sehingga tim audit baru mengirimkan tagihan setelah perusahaan tersebut pailit. Kepailitan PT $\mathrm{X}$ pun diketahui pada saat melakukan penagihan.

2) Pada kepailitan PT Y, karena perusahaan tersebut menempuh upaya hukum berupa keberatan dan banding, DJBC tidak melakukan upaya preventif terkait dengan pengamanan aset PT Y, sehingga pada saat kepailitannya, PT Y sudah mengalihkan aset-asetnya.
3) Pada kepailitan PT Z, waktu yang lama pada prosedur penagihan telah dimanfaatkan oleh PT $\mathrm{Z}$ untuk menyamarkan asetnya sebelum perusahaan tersebut pailit.

Terkait dengan penyelamatan hak Negara, berdasarkan studi kasus pada PT X, PT Y, dan PT Z, tindakan DJBC berupa penagihan aktif juga tidak berhasil mengamankan hak Negara. Menurut Bapak Purnomo, tindakan DJBC terhadap praktik penghindaran pajak pada kepailitan PT Y dan PT Z tidak efektif karena telah terjadi pengalihan asset sebelum pailitnya perusahaan sebagaimana pernyataan berikut:

\section{"...dugaan penghindaran pajak ya seperti itu, mereka tidak mau bayar, ketika ditagih, aset disamarkan atau dialihkan ke saudaranya atau afiliasinya....."}

Menurut Bapak Hari Setyo, tindakan DJBC tidak akan efektif karena pemblokiran hanya sebatas NPWP perusahaan sebagaimana dinyatakan sebagai berikut:

"Sistem kita hanya mengunci NPWP
perusahaannya, belum sampai NPWP
pengurus, sehingga seseorang kalau bikin
perusahaan baru lagi ya sudah tidak terlacak
utang-utang diperusahaan lama"

Tindakan yang dilakukan DJBC selama ini kepada perusahaan pailit yang mempunyai utang pajak di bidang impor, dinilai belum efektif baik dari sisi pencegahan maupun dari sisi penyelamatan hak Negara karena efektivitas diartikan sebagai keberhasilan dalam pencapaian target atau tujuan (Handayaningrat, 1996). Hal ini terlihat dari tingkat keberhasilan penagihan aktif yang rendah serta data piutang tidak tertagih pada perusahaan pailit yang terus meningkat (Tabel 1).

\section{KESIMPULAN}

Hasil penelitian menunjukkan bahwa telah terjadi praktik penghindaran pajak di bidang impor pada kepailitan ketiga perusahaan ekspor impor tersebut, yaitu dengan memanfaatkan keterlambatan tagihan (PT X) dan penyamaran aset (PT Y dan PT Z). Hal tersebut dilakukan dengan memanfaatkan berbagai celah, baik pada ketentuan maupun pada proses penagihan. Terkait dengan motivasi kepailitan, diketahui bahwa PT Y (importir umum) telah menjadikan kepailitan sebagai modus penghindaran pajak di bidang impor, sedangkan pada PT X dan PT Z diduga hanya mengambil manfaat dari pailitnya perusahaan tersebut untuk menghindari pajak di bidang impor. Sesuai dengan Teori GONE dan Teori Ramirez Torres, hal ini terjadi karena adanya sikap mental yang tidak baik, kesempatan, hukuman yang ringan (tidak membuat jera), hasil yang besar dan kemungkinan tertangkap kecil.

Berdasarkan studi kasus pada PT X, PT Y dan PT $Z$, upaya penagihan yang telah dilaksanakan tidak 
mendapatkan hasil yang diharapkan karena banyaknya kendala seperti lemahnya pengawasan dan kurangnya informasi terkait dengan perusahaan pailit tersebut. Hal ini terjadi karena upaya penagihan DJBC selama ini dilakukan dengan cara konvensional, yaitu menunggu waktu jatuh tempo, memberikan surat teguran, menerbitkan surat paksa, kemudian melakukan penyitaan tanpa melakukan upaya preventif.

Tindakan yang dilakukan DJBC selama ini terhadap perusahaan pailit yang mempunyai utang pajak di bidang impor, dinilai belum efektif baik dari sisi pencegahan maupun dari sisi penyelamatan hak Negara. Pada upaya penagihan yang dilakukan terhadap PT X dan PT Z, DJBC sama sekali tidak mendapatkan bagian. Hal ini juga didukung oleh data SAPP yang menunjukkan rendahnya tingkat keberhasilan penagihan aktif pada perusahaan pailit serta data piutang tidak tertagih pada perusahaan pailit yang terus meningkat.

\section{IMPLIKASI DAN KETERBATASAN}

Secara teoritis, implikasi dari penelitian ini adalah menambah khazanah keilmuan pada bidang akuntansi pemerintahan khususnya mengenai praktik penghindaran pajak yang terjadi di Direktorat Jenderal Bea dan Cukai. Penelitian ini juga memberikan gambaran dan pemaparan mendalam atas praktik penghindaran pajak yang terjadi karena adanya kesempatan, hukuman yang tidak memberi efek jera, serta kecilnya peluang tertangkap sesuai dengan Teori GONE dan Teori Ramirez Torres.

Pada praktiknya, penelitian ini memiliki kontribusi bagi DJBC agar upaya preventif dan represif dapat dilakukan dengan memahami berbagai praktik penghindaran pajak di bidang impor pada kepailitan perusahaan ekspor impor, antara lain dengan mewaspadai kepailitan importir dengan karakteristik tertentu. Hasil penelitian ini diharapkan dapat ditindaklanjuti dengan melakukan evaluasi terhadap tindakan dan kebijakan yang selama ini dijalankan.

Penelitian tidak terlepas dari beberapa keterbatasan. Pertama, kasus yang diteliti menyangkut nama baik seseorang yang dilindungi oleh UU Keterbukaan Informasi Publik, sehingga data yang dapat diambil untuk dipublikasikan terbatas. Kedua, kasus yang diteliti berada dalam area abu-abu, sehingga informan dari pelaku usaha tidak dapat membuka semua hal menyangkut perusahaan yang diteliti karena keterbatasan dan kerahasiaan informasi, bahkan terdapat informan yang menolak diwawancarai.
Handayaningrat, S. 1996. Pengantar Studi Ilmu Administrasi Dan Manajemen. Jakarta: Gunung Agung.

Hutagaol, J. 2007. Perpajakan: Isu-isu Kontemporer. Yogyakarta:Graha Ilmu.

Moleong. 2005. Metodologi Kualitatif Edisi Revisi. Bandung: PT Remaja Rosdakarya.

Zarkasi, Ahmad. 2012. Analisis Data Penelitian Kualitatif. Palangkaraya: STAIN Palangkaraya.

\section{Buku Terjemahan}

Newton, G. W. 2009. Bankruptcy and Insolvency Accounting 7th Edition. New Jersey:Wiley

\section{Jurnal}

Dinis, A., C. Lopes, and A. Silva. 2015. "Tax Evasion And Tax Fraud In The Bankruptcy Process:Empirical Evidence From Portugal". Working Paper Observatório de Economia e Gestão de Fraude No. 36/2015

Johannesen, Niels. 2014. "Tax Avoidance with CrossBorder Hybrid Instruments." Journal of Public Economics, Vol. 112, pp. 40-52

Liu Xuepeng. 2013. "Tax Avoidance Trough Re-Impor: The Case of Redundant Trade." Journal of Development Economics, Vol.104, pp.152164

Matei, A. D. 2013. "Could The Present EconomicFinancial Crisis Give A New Impetus To The Fight Against Corruption And The Underground Economy?" Journal of Internal Auditing and Risk Management, Vol. 8, No.2, pp.31-42

Nurina Devi, E. P. 2014. "Faktor-Faktor Penentu Aliran Masuk Foreign Direct Investment Di Indonesia Periode 2001-2013". Tesis Tidak Dipublikasikan: UAJY

Ramadhani, Bravika Bunga. 2009. "Penyelesaian Utang Piutang Melalui Kepailitan.” Tesis Tidak Dipublikasikan: UNDIP

Richardson, G., G. Taylor, and R. Lanis. 2015. "The Impact of Financial Distress on Corporate Tax Avoidance Spanning Global Financial Crisis : Evidence from Australia." Journal of Economic Modelling, Vol.44, pp.44-53

Taylor, G. and G. Richardson. 2011. "International Corporate Tax Avoidance Practice: Evidence from Australian Firms." The International Journal of Accounting, Vol.47, pp.469-496

Tedika, O. K., I. K. Kanyana, and F. Aziadimbu. 2013. "Alcohol and Corruption" Journal of Advanced Research in Law and Economics, Vol 4, No.8, pp. 14-157

Xynas, Lidia .2011. "Tax Planning, Avoidance And Evasion In Australia 1970-2010: The Regulatory Responses And Taxpayer Compliance." Revenue Law Journal, Vol. 20, No. 1, pp.1-39

\section{Sumber Buku}


Karya Ilmiah

Sihombing, Kennedy. 2014. "Analisis Fraud Diamond Dalam Mendeteksi Financial Statement Fraud : Studi Empiris Pada Perusahaan Manufaktur Yang Terdaftar Di Bursa Efek Indonesia (BEI) Tahun 2010-2012." Skripsi tidak dipublikasikan: UNDIP

Suwitno, Lanny. 2013. "Perbandingan Ketepatan Bankruptcy Prediction Models Untuk Memprediksi Financial Distress Dan Kepailitan Pada Perusahaan Manufaktur Yang Terdaftar Di Bursa Efek Indonesia". Tesis Tidak Dipublikasikan: UAJY

Naskah dari Internet

Badan Pusat Statistika, 2015, Data Impor Tahun 20002015, http://www.bps.go.id/ diakses 4 Maret 2015.

Direktorat Jenderal Bea dan Cukai. 2015. http://www.beacukai.go.id. Diakses tanggal 1 Juli 2015.

Gravelle, Jane. 2015. "Tax Haven: International Tax Avoidance and Tax Evasion", http://digitalcommons.irl.cornel.edu/key_ workplace. Diakses tanggal 11 Agustus 2015.

Harjanti, Adriana Dwi. 2015. "Antara Upah buruh dan Utang Pajak", http://www.bppk.depkeu.go.Id/publikasi/Ar tikel/167-Artikel-Pajak/20492-Upah-BuruhVs-Utang-Pajak,Mana-Yang-DidahulukanPembayarannya, diakses 5 Februari 2015.
Harjono, D. 2009. "Hukum Bisnis", http://www.hukumonline.com/ berita/baca/hol20865/dr-dhaniswaraharjono-sh-mh-hukum-bisnis-kita-lagi-krisis, diakses 5 Februari 2015.

Key, J. P. 1997. "Qualitative Research", http://www.okstate.edu/ag/agedcm4h/ academic/aged5980a/5980/ newpage21.htmOklahoma. Diakses tanggal 1 Agustus 2015.

Medina, J. R. S. 2012. "Implicaciones Fiscales De La Reforma Concursal", http://www.diariojuridico.com/implicacione s-fiscales-de-la-reforma-concursal, diakses 10 Oktober 2015

Suryana, Anandita Budi. 2013. "Menisik Pajak Perusahaan Global" http://www.pajak.go.id/content/article/me nisik-pajak-perusahaan-global, diakses $7 \mathrm{Mei}$ 2015.

Tosi, L. 2005. "Problematiche Fiscali Del Fallimento E Prospettive Di Riforma". http://hdl.handle.net/10278/3448, diakses 1 Juli 2015.

Naskah Produk Kebijakan

Undang-Undang No. 31 Tahun 1999 yang telah diubah dengan Undang-Undang No. 20 Tahun 2001 tentang Pemberantasan Tindak Pidana Korupsi.

Undang-Undang Nomor 37 Tahun 2004 tentang Kepailitan dan Penundaan Kewajiban Pembayaran

Utang. 